\title{
Evaluation of workplace accident-related admissions: A study of 1-year experience
}

\section{İş kazası iliş̧kili başvuruların değerlendirmesi: Bir yıllık deneyim}

\author{
Harun Gunes ${ }^{1}$, Hallit Berk Canga ${ }^{2}$
}

Balikesir University School of Medicine Department of Emergency Medicine, Balıkesir, Turkey

${ }^{2}$ Duzce University School of Medicine Department of Emergency Medicine, Duzce, Turkey

Corresponding author: Harun Gunes, MD, Balikesir University School of Medicine Department of Emergency Medicine, Balikesir, Turkey

E-mail: haroonsun@hotmail.com

Received/Accepted: March 08, 2019 /September 29, 2019

Conflict of interest: There is not a conflict of interest.

\begin{abstract}
SUMMARY
Objective: To contribute to the national data on the subject by analyzing WA-related ED admissions during a 1-year period in our center.

Method: Cases admitted to our hospital due to a WA during a 1-year period were enrolled in the study. Information regarding gender, age, accident date, injury mechanism, injured body parts, consultations, diagnoses, severity of the injury, outcome of the patient and the services which the admitted patients were admitted to were gathered. $\mathrm{p} \leq .05$ was considered to be significant.

Results: Three hundred and eighty patients were enrolled in the study. A great majority of the victims $(88.4 \%)$ were male. Mean age of the cases was $34.88 \pm 9.74$ years. The month with the highest number of admissions was June (11.1\%). WA victims mostly presented during day-time period $(54.7 \%)$. Contact with sharp objects was the most common injury mechanism (34.2\%). More than one third of the cases were consulted with at least one department (34.2\%). Upper extremities were the most commonly injured body parts (51.3\%). The most common diagnosis was mild soft tissue injury (40.0\%). Most of the cases (86.6\%) were discharged from the emergency department; $12.6 \%$ were admitted to our hospital; $.8 \%$ were referred to another health care facility, and none of the patients died in the emergency department.

Conclusions: WAs mostly affect young male workers; most of the WAs occur during day-time period; WAs mostly occur as a result of contact with sharp objects; mostly upper extremities are affected in which hands are the most commonly injured part, and hand fingers form the part which has the highest possibility of injury.

Keywords: Contact with sharp objects, hand injury, hand finger injury, upper limb injury, workplace accident, work accident
\end{abstract}

Harun Gunes

(D) Halit Berk Canga

\section{ÖZET}

Amaç: Merkezimize 1 yıllık dönemde başvuran iş kazası ilişskili olguları analiz ederek konu hakkındaki ulusal verilere katkıda bulunmak.

Yöntem: Hastanemize 1 yıllık dönemde iş kazası sonucu başvuran olgular çalışmaya dahil edildi. Cinsiyet, yaş, kaza tarihi, yaralanma mekanizması, yaralanan vücut bölgesi, konsültasyonlar, tanılar, yaralanmanın ciddiyeti, hastanın akıbeti ve yatış yapılan hastaların hangi servislere yatırıldığı ile ilgili bilgiler toplanıp kaydedildi. İstatistiksel analizlerde Windows için Sosyal Bilimler İstatistik Paketi (SPSS) programı kullanıldı. $\mathrm{p} \leq 0,05$ anlamlı kabul edildi. 
Bulgular: Çalışmaya 380 hasta dahil edildi. Kurbanların büyük çoğunluğu $(\% 88,4)$, erkekti. Olguların yaş ortlaması, $34,88 \pm 9,74$ y1ldı. En çok olgunun görüldüğü ay, Haziran'd1 (\%11,1). İș kazası kurbanları çoğunlukla gündüz başvurmuştu $(\% 54,7)$. En sık yaralanma mekanizması, keskin cisimle temastı $(\% 34,2)$. Olguların üçte birinden fazlası en az bir bölüme konsülte edilmişti $(\% 34,2)$. Üst ekstremiteler, en çok yaralanan vücut parçasıydı ve iş kazası başvurularının çoğu üst ekstremite yaralanması nedeniyle gerçekleşmişti $(\% 51,3)$. En sık tanı, hafif yumuşak doku yaralanmasıdıdı $(\% 40,0)$. Olguların çoğu acil servisten taburcu edilmişti (\%86,6); \%12,6'sı hastanemize yatııılmış; \%0,8’i başka bir merkeze sevk edilmişti. Acil serviste hayatını kaybeden olgu yoktu.

Sonuç: Çalışmamızda elde edilen bulgulara göre iş kazaları çoğunlukla genç erkek çalışanları etkiler. İş kazalarının çoğu gündüz meydana gelir ve çoğunluğundan keskin cisimle temas, sorumludur. Çoğunlukla üst ekstremite ve en sik da eller etkilenir; ellerin yaralanma açısından en yüksek risk altındaki bölümü parmaklardır.

Anahtar sözcükler: El yaralanması, el parmak yaralanması, iş kazası, iş yeri kazası, keskin cisimle temas, üst ekstremite yaralanmasi

\section{INTRODUCTION}

A workplace accident (WA) also referred to as work accident is generally defined as an unplanned event causing personal injury or harm to the equipment and machines and temporary lag of production ${ }^{1}$. WAs are significant health problems worldwide ${ }^{2}$. International Labor Organization (ILO) reports show that 1 worker every 3 minutes dies related to a WA or an occupational disease worldwide, and nearly 110 million workers have a WA or an occupational disease annually ${ }^{3}$. It is estimated that WAs cause 300.000 deaths every year ${ }^{4}$. Seventy thousand to eighty thousand patients present to emergency departments (ED) due to a WA each year in Turkey ${ }^{5}$. The literature includes several studies evaluating WAs in our country ${ }^{1,3,5-8}$. However, no study investigating this topic was conducted in our city. Thus, we aimed to contribute to the national data on the subject by analyzing WA-related ED admissions during a 1year period in our hospital.

\section{MATERIAL AND METHODS}

Patients accepted as forensic cases in the ED between January 1, 2016 and December 31, 2016 were evaluated retrospectively by reading their Forensic Cases Registry Book records, and 383 WA cases were found. Three of those patients were excluded from the study due to lack of sufficient data; remaining 380 patients were enrolled in the study. These 380 patients' data regarding gender, age, admission date and hour, injury mechanism (how the accident occurred), injured body parts, consultations, diagnoses, injury severity, the patient's outcome and services which the hospitalized patients were admitted to were gathered, and all the data were transferred to the Statistical Package for the Social Science (SPSS) for Windows (v15.0). All statistical analyses were performed using this software. The admissions were evaluated with respect to month and season of the admission. Besides, they were evaluated with regard to hour of the admission by dividing a day into 3 equal periods (00:00-08:00 AM [night shift], 08:00 AM-04:00 PM [day-time period], 04:00 PM00:00 o'clock [evening shift]). Finally, the admissions were investigated by dividing a day into 2-hour periods. Descriptive features of the patients were given as number (n), \% frequency and mean \pm standard deviation (SD). Pearson Chisquare test was used to compare categorical variables. Two different groups were compared using Mann-Whitney $U$ test. A p value of $\leq .05$ was considered to be significant.

\section{RESULTS}

Three hundred and thirty six (88.4\%) patients were male, and $44(11.6 \%)$ patients were female. Gender distribution of the patients was found to be statistically significant $(p<0.001)$. Mean age of the patients was $34.88 \pm 9.74$ years; those of the male and female patients were $34.88 \pm 9.61$ years and $34.89 \pm 10.77$ years, respectively. Mean age was found to not differ significantly between male and female patients $(p=0.911)$. June was the month with the greatest number of admissions (n: 42, $11.1 \%$ ) (Figure I), and the season with the highest number of admissions was summer (n: 109, 28.7\%) (Table I). Most of the patients presented during the day-time shift (n: 208, 54.7\%); 127 (33.4\%) patients were admitted during the evening shift, and the night shift was the period with the lowest number of admissions (n: 45, 11.8\%). The 2-hour periods with the highest number of admissions were 11:00 AM-00:59 PM period (n: 64, 16.8\%) and 03:00-04:59 PM period (n: 61, 16.1\%) (Table II). The most common type of injury mechanism was contact with a sharp object (n: 130, 34.2\%) (Table III). Upper extremities were the most commonly injured body parts, and most of the workplace accident admissions occurred due to an upper limb injury (n: 195, 51.3\%) (Table IV). Hand injuries formed most of the upper limb injuries (n: 
$162,83.1 \%$ ), and most of the hand injuries were finger injuries (n: 132, 81.5\%). Lacerations were responsible from most of the hand finger injuries (n: 79, 59.8\%) (Table V). More than one third of the cases (n: $130,34.2 \%)$ were consulted with at least one department, and 7 (1.8\% of total) of these patients were consulted with more than one department. The most common diagnosis was mild soft tissue injury (n: 152, 40.0\%) which is followed by lacerations-cuts (n: 96, 25.3\%) (Table VI). A great majority of the patients had mild injuries which could be treated with simple medical interventions (n: 296, 77.9\%). Six patients only
(1.6\%) had a life-threatening injury. More than three fourths of the patients were discharged after treatment and observation in the ED (n: 329, $86.6 \%)$; $48(12.6 \%)$ patients were hospitalized, and $3(.8 \%)$ patients were referred to another medical facility. Most of the hospitalized patients were admitted by the Plastic and Reconstructive Surgery Department (n: 36, 75.0\%); 6 patients $(12.5 \%)$ by the Orthopedics and Traumatology Department, and $4(1.1 \%)$ patients by other departments. Two patients $(0.5 \%)$ were admitted to an intensive care unit. None of the patients had a fatal outcome in the ED.

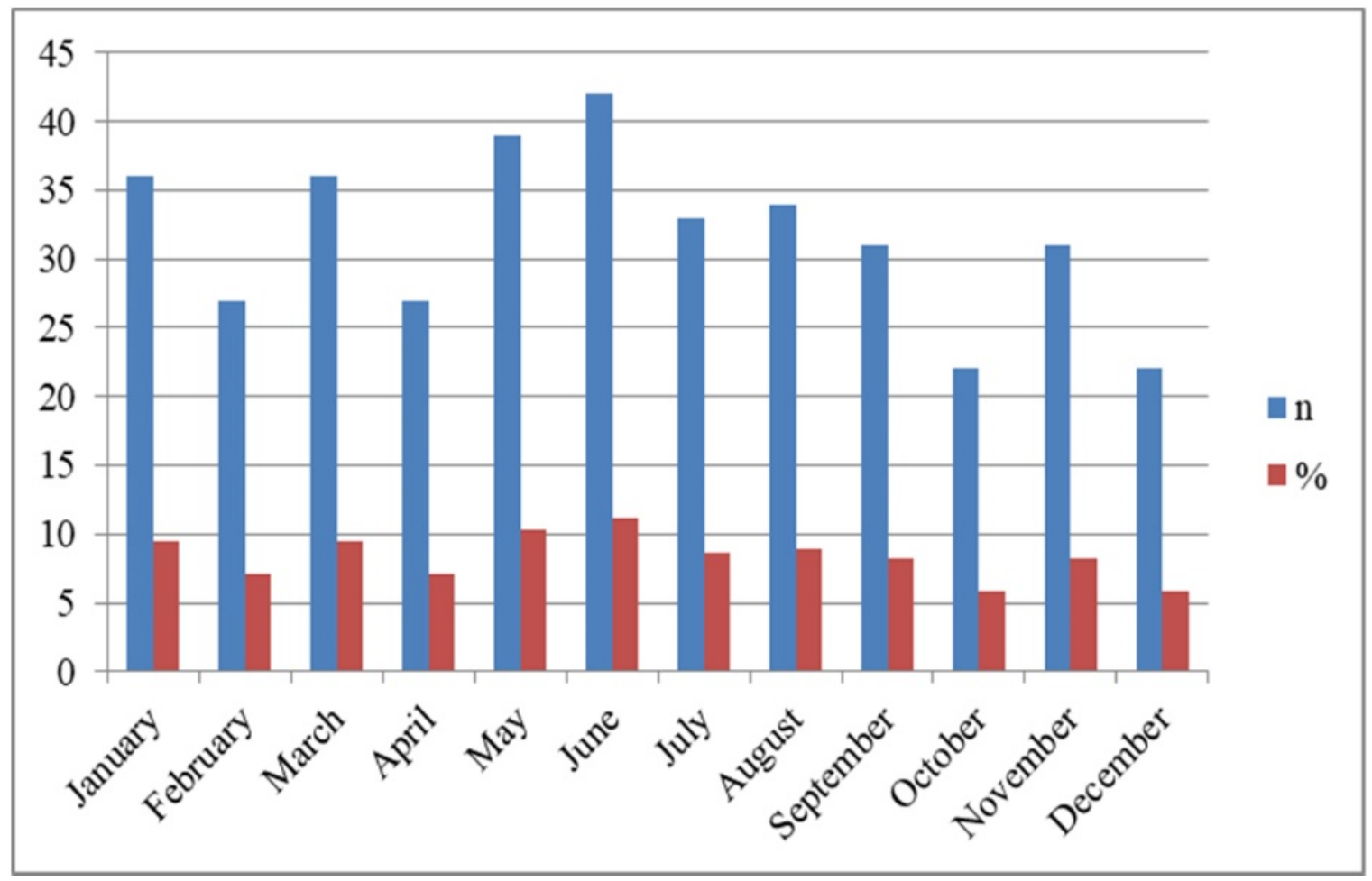

Figure I: Monthly distribution of the admissions. June and May were the months with the highest number of admissions followed by March and January.

Table I: Seasonal Distribution of the Admissions

\begin{tabular}{|l|c|c|c|c|c|c|}
\hline \multicolumn{2}{|l|}{ Season } & Winter & Spring & Summer & Autumn & Total \\
\hline \multirow{2}{*}{ Admissions } & $\mathbf{n}$ & 85 & 102 & 109 & 84 & 380 \\
\cline { 2 - 7 } & $\mathbf{\%}$ & 22.4 & 26.8 & 28.7 & 22.1 & 100 \\
\hline
\end{tabular}


Table II: Admissions grouped into 2-hour periods

\begin{tabular}{|l|l|l|}
\hline \multirow{2}{*}{ 2-hour period } & \multicolumn{2}{|c|}{ Admissions } \\
\cline { 2 - 3 } & \multicolumn{1}{|c|}{ n } & \multicolumn{1}{c|}{$\%$} \\
\hline 07:00-08:59 AM & 18 & 4.7 \\
\hline 09:00-10:59 AM & 49 & 12.9 \\
\hline 11:00 AM-00:59 PM & 64 & 16.8 \\
\hline 01:00-02:59 PM & 44 & 11.6 \\
\hline 03:00-04:59 PM & 61 & 16.1 \\
\hline 05:00-06:59 PM & 42 & 11.1 \\
\hline 07:00-08:59 PM & 33 & 8.7 \\
\hline $09: 00-10: 59$ PM & 23 & 6.1 \\
\hline 11:00 PM-00:59 AM & 10 & 2.6 \\
\hline 01:00-02:59 AM & 8 & 2,1 \\
\hline 03:00-04:59 AM & 13 & 3.4 \\
\hline $05: 00-06: 59$ AM & 15 & 3.9 \\
\hline Total & 380 & 100 \\
\hline
\end{tabular}

Table III: Distribution of the cases according to injury mechanism

\begin{tabular}{|l|l|l|}
\hline \multirow{2}{*}{\multicolumn{1}{c|}{ Injury Mechanism }} & \multicolumn{2}{c|}{ Admissions } \\
\cline { 2 - 3 } & \multicolumn{1}{c|}{ n } & \multicolumn{1}{c|}{$\%$} \\
\hline Fall & 82 & 21.6 \\
\hline Fall from a height & 14 & 3.7 \\
\hline Contact with a sharp object & 130 & 34.2 \\
\hline Burn & 8 & 2.1 \\
\hline Blunt trauma & 89 & 23.4 \\
\hline Penetrating trauma & 40 & 10.5 \\
\hline Toxic gas inhalation & 17 & 4.5 \\
\hline Total & 380 & 100 \\
\hline
\end{tabular}


Table IV. Injured body parts

\begin{tabular}{|l|l|l|}
\hline \multirow{2}{*}{ Injured body part } & \multicolumn{2}{|c|}{ Admissions } \\
\cline { 2 - 3 } & $\mathbf{n}$ & \multicolumn{1}{|c|}{$\%$} \\
\hline None & 14 & 3.7 \\
\hline Head-neck & 87 & 22.9 \\
\hline Chest & 9 & 2.4 \\
\hline Abdomen & 7 & 1.8 \\
\hline Back & 15 & 3.9 \\
\hline Upper Limb & 195 & 51.3 \\
\hline Lower Limb & 43 & 11.3 \\
\hline Other & 5 & 1.3 \\
\hline More than one & 5 & 1.3 \\
\hline Total & 380 & 100 \\
\hline
\end{tabular}

Table V: Hand finger injuries

\begin{tabular}{|l|c|c|c|c|}
\hline \multirow{2}{*}{ Type of hand finger injury } & \multicolumn{4}{|c|}{ Admissions } \\
\cline { 2 - 5 } & $\mathbf{n}$ & $\mathbf{\%}$ & Valid \% & Cumulative \% \\
\hline Lacerations & 79 & 20.8 & 59.8 & 59.8 \\
\hline Tendon injuries & 14 & 3.7 & 10.6 & 70.5 \\
\hline Amputations & 14 & 3.7 & 10.6 & 81.1 \\
\hline Fractures & 2 & 0.5 & 1.5 & 82.6 \\
\hline Blunt injury & 17 & 4.5 & 12.9 & 95.5 \\
\hline Other & 3 & 0.8 & 2.3 & 97.7 \\
\hline$>1$ Type of Injuries & 3 & 0.8 & 2.3 & 100 \\
\hline Total (hand finger injuries) & 132 & 34.7 & 100 & \\
\hline Other victims & 248 & 65.3 & & \\
\hline Total & $\mathbf{3 8 0}$ & $\mathbf{1 0 0}$ & & \\
\hline
\end{tabular}


Table VI: Diagnoses of the victims

\begin{tabular}{|l|l|l|}
\hline \multirow{2}{*}{\multicolumn{1}{|c|}{ Diagnosis }} & \multicolumn{2}{c|}{ Admission } \\
\cline { 2 - 3 } & n & \multicolumn{1}{c|}{$\%$} \\
\hline Laceration-cut & 96 & 25.3 \\
\hline Mild soft tissue injury & 152 & 40.0 \\
\hline Hand finger amputation & 14 & 3.7 \\
\hline Upper extremity fracture & 7 & 1.8 \\
\hline Tendon laceration & 17 & 4.5 \\
\hline Eye injury & 38 & 10.0 \\
\hline Lower extremity fracture & 3 & 0.8 \\
\hline Burn & 8 & 2.1 \\
\hline Electric shock & 5 & 1.3 \\
\hline Thoracic fracture & 2 & 0.5 \\
\hline Toxic gas inhalation & 12 & 3.2 \\
\hline Other & 20 & 5.3 \\
\hline$>1$ type of injury & 6 & 1.6 \\
\hline Total & 380 & 100 \\
\hline
\end{tabular}

\section{DISCUSSION}

Almost nine out of ten of the victims enrolled in the current study were male. WAs occurring during the study period affected mostly the younger population. June and summer were the month and season with the greatest number of admissions, respectively. Most of the admissions occurred during day-time period. Approximately one third of the victims were injured due to contact with a sharp object. Upper extremities were the most commonly injured body parts. More than one third of the patients were consulted with at least one department. The most common diagnoses were mild soft tissue injury and lacerations-cuts. More than four fifths of the victims had mild injuries which could be treated with simple medical interventions; most of them were discharged after treatment and observation in the ED, and none had a fatal outcome in the ED.

WAs may result in transient or permanent disability or death ${ }^{9}$. Effects of WAs are not only limited to their effects on victims' health. They lead to occupational and socio-economic consequences for both the victim and the society by resulting in economic losses due to decreased production. Increased work-load of the health sector and related costs are also significant problems ${ }^{10}$. WAs lead to not only personal injury and death of a single worker but also may cause mass injuries and even death of several workers simultaneously.

Male workers more commonly become a victim of a WA than female workers do ${ }^{11-13}$. The results of the present study also support that males are more commonly injured in WAs than are females. We suggest that male predominance among WA victims results from the predominance of male workers employed in jobs with greater risk of WA. Whereas, Serinken et al., in a study investigating WAs among textile industry workers, found out that male workers comprise $23.8 \%$ of WA cases only ${ }^{8}$. We suggest that female workers are expectedly more commonly affected in WAs in the textile industry because markedly more women than men are employed in this special sector.

Mean age of the patients enrolled in the present study was 34.9 years. There are several studies conducted in our country which have apparently 
similar results 1,3,5-7, 11, 12. On the other hand, Serinken et al. found mean age of the victims lower (26.6 years) than that was found in the current study ${ }^{8}$. As it was mentioned previously, Serinken et al. investigated WAs in textile industry in which mostly young female workers are employed so this finding is not surprising. It is noteworthy that WAs mostly affect young workers who could live and work for many years. This feature of WAs contributes to socio-economic insults of the subject. Hence, preventive measures become more important.

The greatest number of WA admissions was seen in June which is followed by May in the current study. The month with the greatest number of admissions was found to be May in the study by Çelik et al ${ }^{1}$, and Satar et al. found that more WA cases were admitted in June, July and August ${ }^{13}$. Karakurt et al. found out that more WA cases occured in December than in any other month ${ }^{12}$. The study by Satar et al. was performed in Adana where the number of workers employed in agricultural sector prominently increases during summer period due to seasonal workers coming from nearby cities so the increase in WAs in June, July and August might be originated from that increase in the number of workers. Although the study by Karakurt et al. was also conducted in Adana, we suggest that a difference in the distribution of patients within the city may explain why Karakurt et al. found that the month with the greatest number of admissions was December. Seasonal variations in the number of WA admissions were also evaluated in our study, and it was seen that more admissions occurred in summer which is followed by spring. Two studies performed in our country evaluated seasonal distribution of WAs previously; both of them found that the season with the greatest number of cases was summer just as it was found in the present study ${ }^{5,13}$. We suggest that increased number of WAs seen during the spring and summer results from increased number of workers due to seasonal workers coming from other cities during this period. Because, this study was performed in a city where a considerable amount of hazelnut and rice production takes place lots of workers come to the region from other cities during summer and spring. Besides, resident workers who live in the region start to work in the fields during these seasons so total number of workers in the region increases markedly during spring and summer which may eventually lead to increased number of WAs.

WAs commonly occur during day-time period ${ }^{1-3,5}$. The present study also found out that WAs mostly occurred during day-time. We suggest that it is an expected finding that most of the WAs occur during day-time because most of the workplaces are open during day-time, and only a small number of factories continue production during the hours outside that period.

Distribution of WAs in a day was also evaluated by dividing a day into 2-hour periods, and it was seen that the 2-hour periods with the greatest number of admissions were 11:00 AM-00:59 PM period and 03:00-04:59 PM period. Serinken et al. reported that most cases of WAs were seen between 07:0009:00 and 23:00-01:00 o'clock ${ }^{8}$. More WAs may be seen in the following a few hours after the beginning of a shift ${ }^{14}$. Because people start to work without sufficiently adapting to the work environment and focusing on their work, WAs may be more commonly seen during these periods. The hours with the greatest number of WAs found by Serinken et al. are the hours when day-time and night shifts begin. On the other hand, the 2-hour periods with the highest number of admissions were following a few hours after the beginning of day-time shift (11:00 AM-00:59 PM) and following a few hours after the lunch (03:00-04:59 PM). There is a phenomenon called "lunch effect" ${ }^{15}$. The "lunch effect" implies increased number of WAs in the afternoon - after the lunch. It was speculated that this effect may be related to the need for a nap after lunch or consumption of alcoholic beverages during lunch. There is a traditional afternoon nap in some countries because people feel tired after the lunch; it is called "siesta" in Spain. We think that a sleepy worker is absolutely a better candidate for a WA. Actually, the 2-hour periods seen to have the greatest number of admissions in the current study are not the first 2-hour periods after the beginning of day-time shift and afternoon period; there are 09:00-11:00 AM period in the morning and 01:00-03:00 PM period in the afternoon before the periods with the greatest number of admissions. However, the present study investigated the time of hospital admission but not the time of accident so there might be a lag between the occurrence of the accident and the admission of the victim to the hospital, and this time lag may explain why the first 2-hour period after the beginning of the shift or in the afternoon is not the one with the greatest number of admissions.

The most common type of injury mechanism was contact with a sharp object in the present study. Sayhan et al. also found out that WAs mostly occur due to contact with sharp objects ${ }^{5}$. The literature includes several studies which have found different injury mechanisms as the commonest one like blunt trauma ${ }^{1}$, a hand caught-in-machinery ${ }^{8}$ or body caught-in-machinery ${ }^{7}$. It is suggested that 
this difference in the most common type of injury mechanism may be originated from the differences in the study design or populations investigated at different studies. For example, the study by Serinken et al. ${ }^{8}$ found out that the most common injury mechanism was a hand caught-inmachinery; we suggest that this finding was a reflection of the study population which was formed by textile industry workers who mostly work their hands close to the moving parts of sewing machine. When the preventive measures are not taken cautiously, workers may experience a WA as a result of exposure to a toxic gas as well as being exposed to physical injury ${ }^{7}$. Seventeen of the patients enrolled in the present study faced WA as a result of exposure to toxic gases. So, each company or factory should individually determine the possible risk factors which may cause a WA and take appropriate preventive measures for every single risk factor to affectively decrease number and severity of WAs as well as taking general measures to prevent injury.

In the present study, upper extremities were the most commonly injured body parts. Besides, most of the WA admissions occurred due to an upper limb injury. Hand injuries formed most of the upper limb injuries, and most of the hand injuries were finger injuries. Lacerations were responsible from most of the hand finger injuries. Upper extremities were the most commonly injured part with a ratio of $43.8 \%$ to $75.1 \%$ in various studies conducted in our country 1,3,5-8, 11, 12. A study performed in Glasgow also found out that half of the WA cases had an upper extremity injury ${ }^{16}$. These findings indicate that upper limbs must certainly be protected against possible traumatic insults especially in the case of a worker who works his hands close to moving machine parts. A glove made of an appropriate material may protect hands and wrists. Besides, some safety controls which can stop the machine in the case of the possibility of a worker is injured may be added to the machines. Upper extremities, hands and hand fingers are very important for a person to work and live independently.

More than one third of patients included in the present study were consulted with another department. That means WA-related admissions have a considerable ratio of consultation need. When an ED patient needs to be consulted with another department he/she stays for a longer period in the ED which results in increased work-load of the ED, and sometimes may contribute to development of the problem no empty ED beds for new patients.
The most common diagnosis was mild soft tissue injury which is followed by lacerations-cuts. Because not all contacts with a sharp object result in a laceration or cut but some of them just cause a superficial abrasion or sometimes closed soft tissue injury, lacerations-cuts form the second most common diagnosis though the most common cause of injury was contact with sharp objects. Similar results were found in various studies performed in our country although there were some classification differences between the studies ${ }^{1,7,12}$.

A great majority of the patients enrolled in the current study $(77.9 \%)$ had mild injuries which could be treated with simple medical interventions. Six patients only $(1.6 \%)$ had a life-threatening injury. Karakurt et al. reported a very close ratio of the patients who had mild injuries that could be treated with simple medical interventions (71.4\%) but a considerably higher ratio of those with a lifethreatening injury $(14.5 \%)^{17}$. It has been suggested that severe injuries including life-threatening ones are rarely seen because new machines have protective mechanisms against severe injuries ${ }^{1}$. Besides, employers generally take preventive measures against severe injuries but some tiny points which are overlooked may still result in simple injuries. Additionally, workers usually behave more careful to avoid severe injuries but they may not be careful enough against simple injuries so simple injuries may occur more commonly.

WA victims are generally discharged after their treatment and observation in ED, and it had been seen in different studies that $51.9 \%$ to $90.0 \%$ of the patients were discharged after ED care, and $7.0 \%$ to $45.9 \%$ had been admitted to various services ${ }^{1,3}$, $5-8,12$. In the present study, it was seen that more than $85 \%$ of the patients were discharged after ED observation; nearly $10 \%$ of the cases only were admitted to the hospital, and 3 patients were referred to another medical facility. Rates of discharge from ED and hospitalization found in the present study are among the rates determined in previous studies. Most of the patients do not need hospitalization because they do not have a severe injury as it was mentioned above.

Patients admitted to our hospital were mostly admitted by the Plastic and Reconstructive Surgery Department $(75.0 \%)$ and the Orthopedics and Traumatology Department (12.5\%). Similar results were found by Karakurt et al. ${ }^{12}$ and Sayhan et al ${ }^{5}$. Similar to the present study, the most commonly injured body part was the extremities in both of these studies so we suggest that hospitalized patients were mostly admitted by the Plastic and 
Reconstructive Surgery Department and the Orthopedics and Traumatology Department. The ratio of patients hospitalized by the Plastic and Reconstructive Surgery Department is apparently higher than that of the ones admitted by the Orthopedics and Traumatology Department because most of the admissions occurred due to an upper limb injury; more than $80 \%$ of upper limb injuries were hand injuries, and the Plastic and Reconstructive Surgery Department deals with hand injuries in our center.

Mortality rates of WA cases vary between $0.2 \%$ and $4.9 \%$ in our country ${ }^{1,3,5-7,12}$. Less than $2 \%$ of the patients had a life-threatening injury, and fortunately none of them had a fatal outcome in the ED. Four patients were transferred to an intensive care unit but their long term follow up is missing so we do not have any information if any of them have died.

It should be noted that the present study has some limitations. First, it was designed as a retrospective study thus some important points like the sector WA occurred in, the exact time of the accident, whether any preventive measures were taken before the accident, whether the accident occurred as a result of the fault of the worker or that of the employer could not be evaluated. Second, our study was performed using the data of a single year, and the number of patients included in the study was relatively small. Third, rates of mortality and permanent disability could not be determined due to lack of long term follow up information. Finally, monthly and seasonal distribution of the admissions might be somewhat affected by the center selection of the patients to admit because the study was designed as a single-center study. For example, patients might prefer to go to other centers in the city during winter months because our center is farther and transportation facilities are limited.

\section{CONCLUSION}

WAs mostly affect young individuals; male workers more commonly become a WA victim; most of the WAs occur during day-time period; WAs mostly occur as a result of contact with sharp objects; mostly upper extremities are affected in which hands are the most commonly injured part, and hand fingers form the part with the highest possibility of injury. Hence, possible risk factors should be determined on sectoral basis and preventive measures against each factor should be taken appropriately to affectively decrease number and severity of WAs. Besides, each company or factory should individually determine unique risk factors which may cause a WA and take appropriate preventive measures against every single factor. We think that the government also has some responsibilities such as making legal regulations to prevent WAs and checking whether these regulations are put into practice. Employers and workers also have some responsibilities in taking preventive measures and putting legal regulations into practice. Additionally, all medical facilities should determine possible WAs which may be seen in their region, and they should always be prepared for them in terms of both the staff and the equipment. Although our study somehow enlightens some aspects of the subject, we suggest that prospective, large scale and multi-centered new studies may help have more in-depth knowledge on the topic.

Acknowledgements $\mathrm{We}$, as the authors, thank Assoc. Prof. Ayhan Saritas for his contributions to the study by encouraging us to start the study.

\section{REFERENCES}

1. Celik K, Yilmaz F, Kavalci C, et al. Occupational injury patterns of Turkey. World $\mathrm{J}$ Emerg Surg. 2013;8(1):57.

2. Ng ZX, Teo LT, Go KT, Yeo YT, Chiu MT. Major workplace related accidents in Singapore: A major trauma centre's experience. Ann Acad Med Singapore. 2010;39(12):920-7.

3. Dağlı B, Serinken M. Occupational Injuries Admitted to the Emergency Department The Journal of Academic Emergency Medicine. 2012;11:167-70.

4. Takala J, Hamalainen P, Saarela KL, et al. Global estimates of the burden of injury and illness at work in 2012. J Occup Environ Hyg. 2014;11(5):326-37.

5. Sayhan MB, Sayhan ES, Yemenici S, Oguz S. Occupational injuries admitted to the emergency department. J Pak Med Assoc. 2013;63(2):179-84.

6. Akdur O, Ozkan S, Durukan P, et al. Machinerelated farm injuries in Turkey. Ann Agric Environ Med. 2010;17(1):59-63.

7. Ozkan S, Kilic S, Durukan P, et al. Occupational injuries admitted to the Emergency Department. Ulus Travma Acil Cerrahi Derg. 2010;16(3):241-7.

8. Serinken M, Turkcuer I, Dagli B, et al. Workrelated injuries in textile industry workers in Turkey. Ulus Travma Acil Cerrahi Derg. 2012;18(1):31-6.

9. Concha-Barrientos M, Nelson DI, Gingerhut M, Driscoll T, Leigh J. The global burden due to 
occupational injury. Am J Ind Med. 2005;48(6):470-81.

10. Santana VS, Souza LE, Pinto IC. Health care costs and the socioeconomic consequences of work injuries in Brazil: a longitudinal study. Industrial Health. 2013;51(5):463-71.

11. Ince $\mathrm{H}$, Ince $\mathrm{N}$, Ozyildirim BA. Occupational accidents and forensic medicine in Turkey. J Clin Forensic Med. 2006;13(6-8):326-30.

12. Karakurt Ü, Satar S, Açıkalın A, Bilen A, Gülen M, Baz Ü. Analysis of Occupational Accidents Admitted to the Emergency Medicine Department. The Journal of Academic Emergency Medicine. 2013;12:19-23.

13. Satar S, Kekec Z, Sebe A, Sar1 A. Analysis of Occupational Accidents Admitted to the Cukurova University Faculty of Medicine Emergency Department. Cukurova Medical Journal. 2004;29:118-27.
14. Lombardi DA, Sorock GS, Hauser R, et al. Temporal factors and the prevalence of transient exposures at the time of an occupational traumatic hand injury. J Occup Environ Med. 2003;45(8):832-40.

15. Camino Lopez MA, Fontaneda I, Gonzalez Alcantara OJ, Ritzel DO. The special severity of occupational accidents in the afternoon: "the lunch effect". Accid Anal Prev. 2011;43(3):1104-16.

16. Macdonald DJ, Sanati KA, Macdonald EB. The costs and characteristics of occupational injuries admitted to a trauma unit. Int J Occup Saf Ergon. 2012;18(4):587-90. 